Open Access

\title{
Are Japanese digital natives ready for learning english online? a preliminary case study at Osaka University
}

\author{
Parisa Mehran ${ }^{1 *}$, Mehrasa Alizadeh ${ }^{1}$, Ichiro Koguchi ${ }^{2}$ and Haruo Takemura ${ }^{1}$
}

\author{
* Correspondence: \\ mehran.parisa@lab.ime.cmc.osaka- \\ u.ac.jp \\ ${ }^{1}$ Cybermedia Center, Toyonaka \\ Educational Research Center, Osaka \\ University, 1-32 Machikaneyama, \\ Toyonaka, Osaka 560-0043, Japan \\ Full list of author information is \\ available at the end of the article
}

\begin{abstract}
Assessing learner readiness for online learning is the starting point for online course design. This study thus aimed to evaluate Japanese learners' perceived e-readiness for learning English online prior to designing and developing an online EGAP (English for General Academic Purposes) course at Osaka University. A sample of 299 undergraduate Japanese students completed a translated and adapted version of the Technology Survey developed by Winke and Goertler (CALICO Journal 25(3): 482-509, 2008). The questionnaire included items about respondents' ownership of and access to technology tools, their ability in performing user tasks from basic to advanced, their personal educational use of Web 2.0 tools, and their willingness to take online English courses. The informants were found to have personal ownership and/or adequate access to technological devices and the Internet at home or at the university. While their keyboarding skills have been reported as relatively low, the self-assessment data indicates that the participants know about general Web 2.0 tools and utilize them in daily life but not within educational settings. The students were also in general unwilling to take online courses, either fully online or blended. This finding further highlights the necessity of digital literacy training before implementing the prospective online course with a focus on EGAP.
\end{abstract}

Keywords: e-readiness assessment, Online language learning, Online course design

\section{Introduction}

When one thinks of Japan today, technology quickly springs to mind alongside the images of sushi, cherry blossoms, and kimonos. Japan is in fact a technology-driven country that manufactures millions of high-tech gadgets; however, digital literacy levels are comparatively low amongst its generation of digital natives, a term coined by Prensky (2001). Anecdotal evidence suggests that while Japanese university students are skillful at using smartphone applications such as LINE and are even occasionally addicted to gaming, many are not avid technophiles when it comes to education. Therefore, availability and accessibility of computer technology do not necessarily guarantee its usability, and that is why technology has not yet been normalized, in Bax's (2011) terms, in Japanese educational settings. Against all odds, some strides have been taken to incorporate technology into education at secondary and tertiary levels especially through online education (MEXT 2011).

(c) The Author(s). 2017 Open Access This article is distributed under the terms of the Creative Commons Attribution 4.0 International License (http://creativecommons.org/licenses/by/4.0/), which permits unrestricted use, distribution, and reproduction in any medium, provided you give appropriate credit to the original author(s) and the source, provide a link to the Creative Commons license, and indicate if changes were made. 
Online education has been regarded as beneficial in that it supports learning by enhancing students' motivation, providing interactive digital environments, adding multimodality, fostering communication and collaboration, increasing self-management and self-assessment, encouraging out-of-class learning, and helping students develop $21^{\text {st }}$ century skills to become autonomous, capable, and participatory digizens (digital citizens) motivated for lifelong learning (Ng 2015). Furthermore, by exceeding the boundaries of time and location, the Internet enables instructors and learners to communicate with one another both synchronously and asynchronously, in pairs or groups anywhere anytime (Bates and Sangrà 2011). By and large, online instruction can offer numerous advantages including flexibility, accessibility, independency, interactivity, multimodality, cost-effectiveness, ubiquitous learning, convenience, and learner-centeredness (Moore 2013).

Unlike other disciplines, language instruction in online environments has only recently begun to establish its legitimacy and gain popularity in a variety of forms, namely Webfacilitated, blended or hybrid as well as fully virtual or online courses (Blake 2011). The aforementioned benefits of online learning can also be applied to learning English online, where technology-enhanced language learning environments have facilitated interaction, collaboration, and communication with a wider audience; provided comprehensible input; developed cognitive abilities; offered task-based, problem-solving, and student-centered activities; promoted learner autonomy; responded to student needs; enhanced cultural insights and competencies; and supplied effective feedback regardless of delivery modes, i.e., Web-enhanced, hybrid, blended, or online (Butler-Pascoe and Wiburg 2003).

In addition to the general advantages of online language learning, such as space saving, lower costs, flexibility in time and location, standardization in educational programs, improvement of instruction through using the class time efficiently, providing immediate feedback, and tracking students' progress and evaluating their engagement (Goertler et al. 2012), the online environment can particularly help Japanese learners who feel anxious or shy by allowing them to personalize their learning in their own way and at their own pace, which motivates researchers (e.g., Bracher 2013; McCarty 2007; Shudong et al. 2005) to design online courses in Japan.

As the major stakeholders in online language instruction, learners should be prepared for success in CALL (Computer Assisted Language Learning) by having ready access to hardware and software in addition to being technologically literate. By contrast, many CALL practitioners fail to address learner e-readiness - the degree to which a learner is ready for e-learning (Guglielmino and Guglielmino 2003) - as they hastily incorporate technology into their courses (Burrows and Stepanczuk 2013). Consequently, little attention has been paid to learner preparedness for online language learning despite the fact that the literature is abundant with various survey instruments for assessing learner readiness. Examples include Readiness for Education At a Distance Indicator (READI, now known as Smarter Measure) mainly used by higher education institutions, or researcher-designed learner readiness assessment tools such as Fageeh (2011), Hung et al. (2010), Winke and Goertler (2008b), and Xiong et al. (2015). In online instructional design, it is therefore essential to be aware of students' technological knowledge with the aim of delivering content suitable to students' ability levels and training them in computer skills if necessary.

Although the course prerequisites are the mere criterion for students taking face-toface classes, students' e-readiness is yet another issue to be assessed in online courses. 
To "set the stage", online course designers and instructors thus need to evaluate students' online needs and technical skills before starting the instruction (Aisami 2009, p. 1632). In compliance with this requirement, the present study seeks to assess Japanese learners' perceived e-readiness for learning English online as an initial step in designing and developing a Web-based EGAP SPOC (English for General Academic Purposes Small Private Online Course) at Osaka University.

\section{Literature review}

The growth of online language learning: the Japanese context

According to Hockly (2015), there are five main current delivery models for learning a language online ranging from formal to informal approaches: (1) formal online language courses; (2) virtual worlds; (3) LMOOCs (Language Massive Open Online Courses); (4) online language learning communities; and (5) mobile apps for language learning. In the following sections, each of the delivery modes will be explained and exemplified in the context of Japan, in particular Osaka University where applicable.

\section{Formal online language courses}

Formal online language learning usually takes place at schools and universities in the form of credit courses. At Osaka University, “Practical English e-learning” (実践英語 e-learning) courses are an example of formal online language learning, where the students study English online using a commercial package known as Linc English. Some individual instructors at Osaka University also teach with EnglishCentral which is an online English learning platform combining the Web's authentic English videos with a proprietary speech assessment technology (IntelliSpeech" $\left.{ }^{\mathrm{mm}}\right)$.

\section{Virtual worlds}

Virtual worlds, such as Second Life, are online computer-simulated three-dimensional environments where users can interact with one another via avatars for different purposes like business, entertainment, education, or the combination of the two latter ones known as edutainment. Meet-Me is a Japanese virtual world platform which shares many similarities and characteristics with Second Life, and has potential language learning opportunities.

\section{LMOOCs}

Language MOOCs (LMOOCs) are currently in an early stage of development compared to MOOCs from other disciplines. Nevertheless, edX, Coursera, and other well-known platforms are currently witnessing a growing rise in the number of LMOOCs offered by various universities worldwide, which the authors refer to as LMOOC boom. In 2013, the Japan Open Online Education Promotion Council, also known as JMOOC, was established with the aim of promoting open education (Aoki 2015). JMOOC hosts its courses on three official platforms, namely Gacco, Open Learning Japan, and OUJ MOOC. The language MOOCs so far include "TOEIC スト600点突破”, a four-week TOEIC preparation course, as well as “Nihongo Starter", a Japanese course for beginners. OsakaUx has not yet offered any LMOOCs, but a business Japanese MOOC is under preparation. 


\section{Online language learning communities}

Online language learning communities (OLLCs), such as Busuu, Babbel, italki, and Myngle, have become incredibly popular with the phenomenal rise of Web 2.0 and the boom of social networking sites (SNSs). In the Japanese context, Mixi and LINE as the most popular social networking sites have been used to create classroom-based online language learning communities for Japanese learners (e.g., Blyth 2015; McCarty 2009).

\section{Mobile apps for language learning}

The ubiquitous availability of mobile devices in recent years, such as smartphones and tablets, has promoted the rapid development of mobile apps for language learning. In Japan, about $95.6 \%$ of the population have mobile phones (Ministry of Internal Affairs and Communications 2012), including nearly all young university-aged people. The popularity of mobile devices has thus shaped m-learning research in the Japanese setting (for example, the pioneering research of Thornton and Houser 2002, 2003, 2005) and app development for Japanese learners of English (for instance, a series of apps developed by James Rogers, a Japan-based researcher: 英語発音矯正 [English Pronunciation for Japanese Learners], Common English Mistakes of Japanese Learners, English Idioms for Japanese Learners, etc.).

\section{Learner readiness for online language learning}

Warner et al. (1998) have defined learner readiness for online learning as a measure of students' inclination toward online delivery modes versus face-to-face instruction, their competence and tendency to utilize electronic communication, and their ability to undertake autonomous learning; hence, assessing learner e-readiness is highly essential prior to launching an online course. Learner e-readiness has been investigated generally in studies like Smith (2005), Watkins et al. (2004), Palmer and Holt (2009), Hung et al. (2010), Xiong et al. (2015) or across specific disciplines such as nursing (Chong et al. 2011), mathematics (Chiou et al. 2010), and engineering (Akaslan and Law 2011).

Despite recommendations by CALL experts and online language course designers (e.g., Hubbard 2013; Hubbard and Bradin Siskin 2004; Kassen and Lavine 2007; Levy 2006), only a few studies in the realm of language education (Barrette 2001; Burrows and Stepanczuk 2013; Fageeh 2011; Murray and Blyth 2011; and a series of studies by Winke, Goertler, and their colleagues, Goertler 2009; Goertler, Bollen, and Gaff 2012; Winke and Goertler 2008b; Winke et al. 2010), have addressed learner readiness for online language learning before its actual implementation. According to the results of these studies, learner readiness for online language learning is connected with a set of factors which can be broken down into two general categories: demographic variables which incorporate gender, age, grade, nationality, field of study, and technological accessibility/ownership versus non-demographic variables which encompass learner autonomy, motivation, learning style, attitude toward e-learning, language self-efficacy, technological acumen, and online communication skills. Table 1 displays a summary of the studies investigating the factors estimating learner readiness for online language education.

As Hubbard (2013) remarks, the literature on readiness for digital language learning clearly highlights the need for learner training aimed at preparing all students to make effective use of technology-enhanced language learning tasks and activities. He also emphasizes that learner readiness does not only involve technical expertise but also the 
Table 1 Studies on e-learning readiness for online language learning

\begin{tabular}{ll}
\hline Author(s)/year & Variable(s) \\
\hline Barrette (2001) & Computer literacy \\
& \\
& \\
& \\
Winke and Goertler (2008b) & $\begin{array}{l}\text { Ownership and } \\
\text { accessibility of } \\
\text { technology tools, } \\
\text { level of ability } \\
\text { to perform } \\
\text { computer-based } \\
\text { tasks, personal } \\
\text { and academic/professional } \\
\text { use of multimedia } \\
\text { tools, and interest } \\
\text { in hybrid language } \\
\text { instruction }\end{array}$ \\
& Variables assessed in
\end{tabular}

Goertler (2009)

Variables assessed in Winke and Goertler's (2008b) study

Methodology
Three sources of data
collection: (1) pre-training
questionnaire on computer
literacy, (2) records of students'
use of computers for language
learning, and (3) end of
semester questionnaire
on computer literacy.

Results

Basic computer skills

in the beginning significant

improvement

in computer skills

through training

by the end of the

semester

Researcher-made questionnaire estimating

student readiness for

hybrid language

education

High command of computer literacy in general

Inadequate access

to or lack of

competence in

using CALL tools

Need for student

training

Winke and Goertler's

(2008b) questionnaire

High-level computer access and decent yet not advanced enough computer

literacy

Negative perception

of hybrid foreign language instruction

Need for better

access and more training

Winke et al. (2010)

Variables assessed in Winke and Goertler's

Winke and Goertler's

(2008a, 2008b)

Tech-savvy

(2008b) study plus

commonly taught

questionnaire

learners in need

of CALL-specific tools

Lower levels of

computer literacy

and interest in hybrid

language learning

among the learners

of less commonly

taught languages

with non-Roman

alphabets

Necessity of learner

training

Fageeh (2011)

Level of study, computer proficiency,

learner control,

motivation for

learning, and

online communication

self-efficacy

Murray and Blyth (2011) C Computer and Internet literacy/access, software use, skills, and knowledge

Survey and in-depth interviews examining

Students' being ready to accept and use technology and attitude toward

e-learning

$\begin{array}{ll}\text { Adapted from Son et al. (2011) } & \begin{array}{l}\text { High access to } \\ \text { computers } \\ \\ \text { Low level of } \\ \text { computer and } \\ \text { Internet literacy }\end{array} \\ & \begin{array}{l}\text { Inclination toward } \\ \text { Winke and Goertler's }\end{array} \\ \begin{array}{l}\text { (2008b) questionnaire } \\ \text { education due to } \\ \text { the flexibility in time } \\ \text { and place }\end{array}\end{array}$
Winke and Goertler's (2008b) study 
Table 1 Studies on e-learning readiness for online language learning (Continued)

\begin{tabular}{|c|c|c|c|}
\hline $\begin{array}{l}\text { Burrows and Stepanczuk } \\
\text { (2013) }\end{array}$ & $\begin{array}{l}\text { Gender, student level, age, } \\
\text { nationality, field of } \\
\text { study, learner } \\
\text { autonomy, computer } \\
\text { self-efficacy, attitude } \\
\text { toward online learning, } \\
\text { motivation, and } \\
\text { English language } \\
\text { self-efficacy }\end{array}$ & $\begin{array}{l}\text { Researcher-made } \\
\text { questionnaire measuring } \\
\text { learner readiness } \\
\text { for online language } \\
\text { learning }\end{array}$ & $\begin{array}{l}\text { High levels of } \\
\text { computer } \\
\text { self-efficacy for } \\
\text { online language } \\
\text { learning }\end{array}$ \\
\hline
\end{tabular}

ability to understand pedagogical principles and to adapt strategies necessary to successful online language learning.

The findings of studies on language learner e-readiness are of a context-bound nature, highly contingent upon factors such as technological infrastructure of an institution, demographic features of learners (e.g., nationality), and their attitude toward e-learning. To the best of the researchers' knowledge, there has been no study conducted at Osaka University to evaluate the readiness of students for learning English online. This study is thus an attempt to address the research gap by assessing the e-readiness of Japanese undergraduate students at Osaka University prior to designing an EGAP online course.

\section{Methodology}

\section{Case study: Osaka University}

All first- and second-year undergraduate students at Osaka University are required to take English courses as part of their liberal arts education. A typical English class consists of 40 to 55 students (with the majority being Japanese), held once a week for 90 min over a semester of 15 weeks. The instructors are free to select their materials and methods (Hino and Oda 2015). There are also several CALL classrooms, established in 2000 and afterwards, which are equipped with PCs connected to the Internet and other devices such as headsets and printers (Koguchi 2003). Osaka University has been utilizing the commercial LMS Blackboard, also known as CLE (Collaboration and Learning Environment), since 2005 (Takemura 2012).

The practice of CALL is not new to Osaka University. For instance, Takefuta (2015b) has developed a software program called Listen to Me!, containing a collection of digital listening materials aimed at improving the academic listening skills of Japanese learners. Another example is Practical English e-learning, which is a blended English course targeting second-year undergraduate students. The students enrolled in this course mainly use online materials for self-study and meet face to face for a minimum of five required sessions throughout a semester to take achievement tests. Moreover, webOCM (a second LMS for self-study) provides a multimedia dictionary tool capable of translating words on browsers or PDF files with a double-click. This system supports translation from English, German, French, Korean, and Chinese to Japanese (Cybermedia Center 2013).

Despite using technology in face-to-face or blended courses, online English education for general academic purposes is not practiced to its full potential at Osaka University. A number of online ESP courses have been offered, such as "English for Science" 
(Takefuta 2015a), "ESP Course for Biotechnology Conversation" (Nishikawa et al. 2006), "English for Engineering" (Fujita et al. 2009), and "Academic English Communication Skills" for graduate students of science (Noguchi 2003), yet none of them have focused on EGAP. In summary, most of the efforts at incorporating digital materials or online language teaching at Osaka University are instructor-led and are not a longterm sustainable solution, in Ward's (2015) view, to prepare students for study abroad programs or nurture career-ready graduates.

\section{Participants}

A total number of 299 Japanese students at Osaka University participated in this study. The participants were all undergraduate students $(60.2 \%$ freshmen, $33.1 \%$ sophomores, $3.7 \%$ juniors, and 3\% seniors) majoring in humanities $(47.8 \%)$ and science and engineering (52.2\%). One-hundred fifty-six (52.2\%) of them were males, $142(47.5 \%)$ females, and one person identified themselves as other gender $(0.3 \%)$, with a mean age of 19 (ranging from 18 to 24). English was the primary major of $2 \%$ and the minor of only $0.7 \%$ of the participants. The rest were taking English courses as a required or elective subject or for other unspecified reasons. In response to why they were studying English, 65.6\% marked themselves as being interested in the English language and culture, followed by future employment (41.5\%) and communication with native speakers $(48.5 \%)$ as alternative reasons. Table 2 summarizes the participants' demographic information.

Table 2 Participants' demographic profile

\begin{tabular}{|c|c|c|c|}
\hline \multicolumn{2}{|l|}{ Demographic Variables } & \multirow{2}{*}{$\begin{array}{l}\text { Number } \\
156\end{array}$} & \multirow{2}{*}{$\frac{\text { Percent }}{52.2 \%}$} \\
\hline Gender & Male & & \\
\hline & Female & 142 & $47.5 \%$ \\
\hline & Other & 1 & $0.3 \%$ \\
\hline \multirow[t]{4}{*}{ Grade } & Freshman & 180 & $60.2 \%$ \\
\hline & Sophomore & 99 & $33.1 \%$ \\
\hline & Junior & 11 & $3.7 \%$ \\
\hline & Senior & 9 & $3 \%$ \\
\hline \multirow[t]{2}{*}{ Field of Study } & Humanities & 143 & $47.8 \%$ \\
\hline & Science \& Engineering & 156 & $52.2 \%$ \\
\hline \multirow[t]{5}{*}{ English Background ${ }^{a}$} & Primary major & 6 & $2 \%$ \\
\hline & Minor & 2 & $0.7 \%$ \\
\hline & Required for major & 276 & $92.3 \%$ \\
\hline & Elective subject & 30 & $10 \%$ \\
\hline & Other & 49 & $16.4 \%$ \\
\hline \multirow[t]{6}{*}{ Reasons for Studying English ${ }^{a}$} & Interested in English and culture/travel & 196 & $65.6 \%$ \\
\hline & Future job marketing/future employment & 124 & $41.5 \%$ \\
\hline & To be a teacher of English & 9 & $3 \%$ \\
\hline & To communicate with native speakers & 145 & $48.5 \%$ \\
\hline & My family/relatives speak English & 2 & $0.7 \%$ \\
\hline & Foreign language requirement & 44 & $14.7 \%$ \\
\hline
\end{tabular}

${ }^{\mathrm{a}}$ The participants were free to choose more than one answer 


\section{Survey instrument}

An adapted version of the Technology Survey, developed by Winke and Goertler (CALICO Journal 25(3): 482-509, 2008b), was used to collect data from undergraduate Japanese students at Osaka University. The questionnaire was translated into Japanese and content-validated by the researchers (see Additional file 1) to remove the language barrier for the participants. Translating a seminal questionnaire into Japanese can also make a unique contribution to English language teaching research in Japan.

The questionnaire items asked about respondents' ownership of and access to technology tools (such as PCs, laptops, printers, and webcams), their ability in performing user tasks from basic to advanced (e.g., copying and pasting texts and editing videos), their personal and educational use of Web 2.0 tools (for instance, blogs, wikis, podcasts, and social networking websites), and their willingness to take online English courses.

Some modifications were made to adapt the questionnaire to fit the institutional context as well as the research aims, and to add items on the ownership of more recent technological devices. Smartphone, tablet, and CLE are a few examples.

\section{Data analysis}

The collected data were analyzed using SPSS version 22.0 to produce descriptive statistics and frequency distributions. Microsoft Excel 2013 was also utilized to generate charts.

\section{Results}

\section{Ownership of and accessibility to technology tools}

Initially, a number of technology tools (PC desktop computer, PC laptop, Mac desktop computer, Mac laptop, computer speakers, headphones, microphone, printer, webcam, digital camera, and video camera) were listed to examine the participants' ownership of and/or accessibility to those tools alongside their Internet access which are essential to the successful completion of an online course (displayed in Fig. 1). Among the highlighted findings are the students' limited access to Mac desktop computers (18\%) and Mac laptops (19\%), and convenient access to other types of PC laptops (92\%) and smartphones (93\%). Nearly all the participants (94\%) also reported easy access to the Internet.

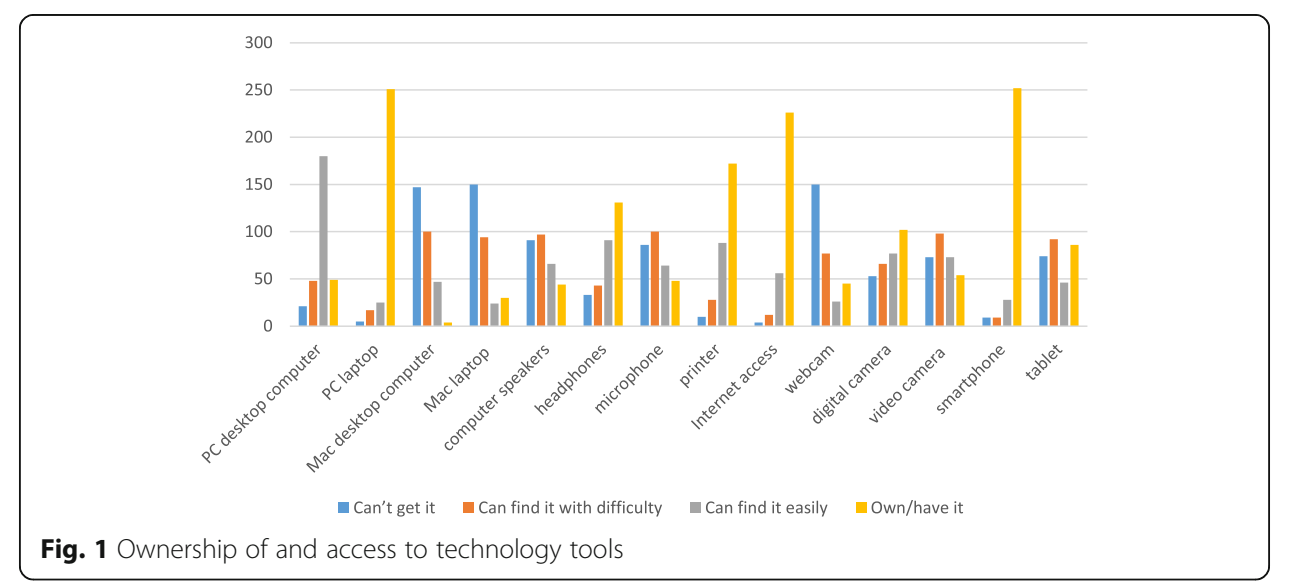




\section{Computer use}

The majority of the participants reported their computer use to be less than two hours per day. Further details are shown in the following pie chart (Fig. 2). Sixty-three percent of the respondents often used on-campus labs for computer use; however, they rarely used the labs for printing.

\section{Level of ability to perform computer-based tasks}

Of the total sample, slightly less than half of the participants (47\%) rated themselves as having poor English typing skills. The participants marked their level of ability to perform a set of computer-based tasks by responding to 25 items which have been grouped into six categories illustrated in Fig. 3.

\section{Keyboarding and formatting documents}

Over half of the participants reported themselves as capable of formatting documents such as cutting, copying, and pasting (83.3\%), adjusting font size and color (76.6\%), inserting pictures (68.6\%), and creating tables (53.5\%). However, the students indicated that they could not easily insert audio and video files in their documents $(33.4 \%)$ or type non-English characters (19.4\%).

\section{Internet know-how}

Most of the students believed that they could navigate the Internet (93\%), save and download files online (82.9\%), and also post messages on social networks and online bulletin boards (73.2\%). The respondents rated themselves as low in developing and maintaining websites (12.7\%) and in downloading and unzipping ZIP files (39.4\%).

\section{Playing audio/video}

As the participants reported, they could effortlessly play audio files from the Web and from their computers $(80.9 \%)$ and play a video on a website, on their computers, or stored on DVDs (86.3\%).

\section{Emailing}

The participants found themselves more comfortable with sending $(84.7 \%)$ and forwarding (74.9\%) emails and sending and opening attachments (83\%) than having access to emails from computers other than their own (63.5\%) and creating new email accounts (69.9\%).

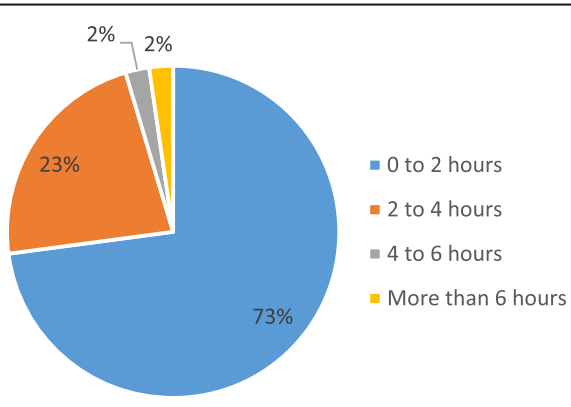

Fig. 2 Computer use per day 


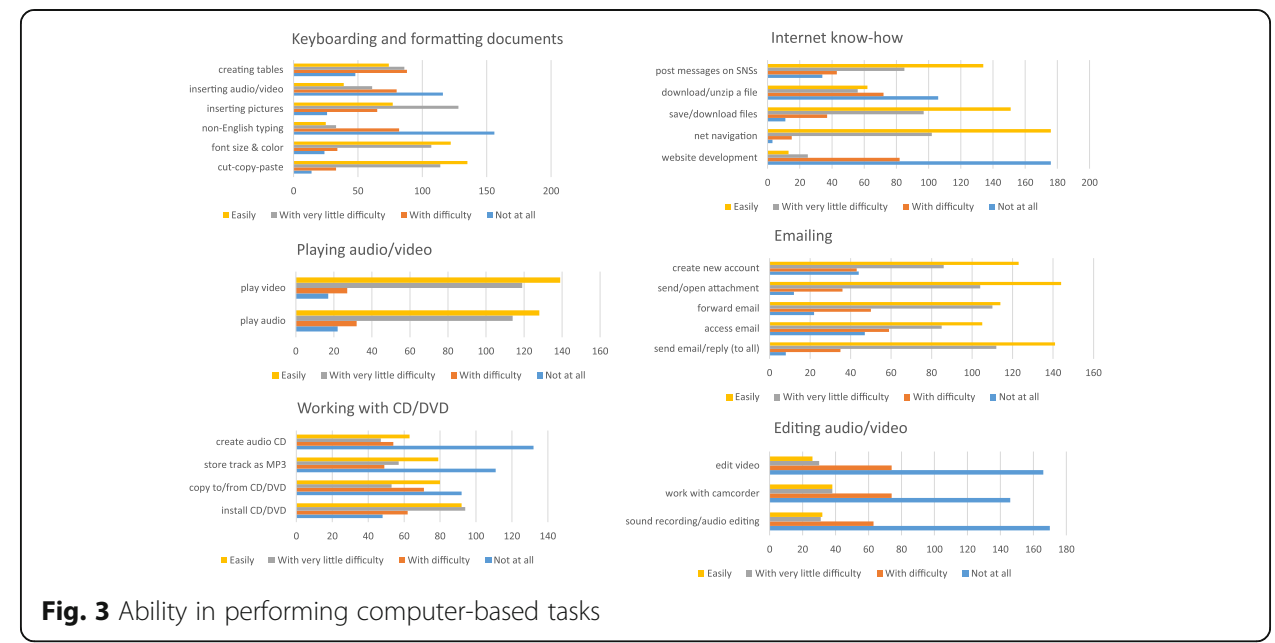

\section{Working with CD/DVD}

The responses indicated that $62.2 \%$ of the students could install a program directly from a CD/DVD, $44.5 \%$ of them could copy files to or from CD/DVD, $45.5 \%$ were able to store a track as MP3, and only $36.8 \%$ could create an audio CD "easily" or "with little difficulty".

\section{Editing audio/video}

The participants did not feel confident in making sound recordings and audio editing (21.1\%), working with camcorders (25.4\%), and editing videos (18.7\%). The numbers within parentheses show the percentage of the students who could carry out the audio/ video editing tasks either "easily" or "with little difficulty".

\section{Familiarity with and use of multimedia tools}

The last section of the questionnaire asked the participants to rate their extent of familiarity with and use of a number of multimedia tools on a five-level scale: (1) do not know; (2) use in personal life; (3) use in non-language classes; (4) use in language class; and (5) useful for language learning.

The word clouds in Fig. 4 demonstrate the degree to which the respondents were familiar with multimedia tools and whether they used them in daily life, nonlanguage and language classes. A number of the participants were not acquainted with several tools and platforms such as Second Life (72\%), podcasts/videocasts (49\%), discussion boards (49\%), video chat (46\%), blogs (35\%), iPads (40\%), and iPods (35\%). Emails (74\%), websites (71\%), SMS (58\%), and SNSs (67\%) were among the tools frequently used by the students in their daily lives. According to the students' self-report, CLE and course websites were often utilized in both nonlanguage and language classes. Online exercises and quizzes as well as CDs/DVDs were also favored in language classes. In general, multimedia tools were used less than one hour per week as reported by $54.5 \%$ of the students, and were more often used in daily life rather than in educational contexts.

With regard to the usefulness of the multimedia tools in language learning, online exercises and quizzes, CDs/DVDs, and websites received the highest rank. 


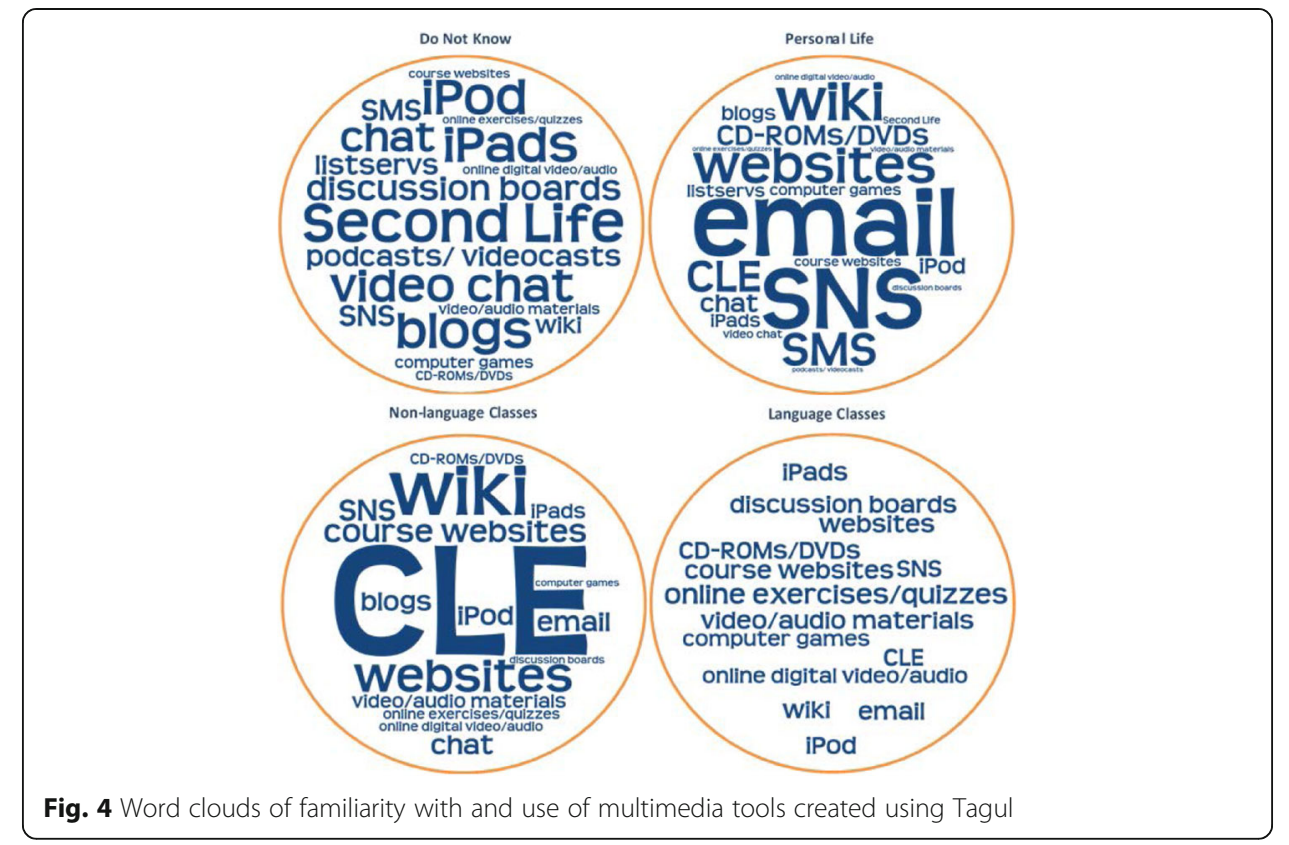

Interest in online language learning

On the one hand, $36.8 \%$ of the students were willing, 36.1\% were uncertain, and $26.1 \%$ were reluctant to take a purely online English course. On the other hand, $32.4 \%$ of them expressed their desire to take a blended English course, 34.4\% were doubtful, and $32.1 \%$ were unwilling. Overall, the participants were hesitant to take either a fully online or blended course of English.

\section{Discussion}

\section{Digital possession, access, and use in high-tech Japan}

The current study investigated the digital possession, access, and use of technology tools by Japanese learners of English. In spite of the unpopularity of Mac devices among the students, the majority of them either own or have easy access to PC desktops, smartphones, and also the Internet. This finding comes as no surprise given that Japan is a high-resource context. Nevertheless, the computer use is limited to two hours per day probably due to excessive use of smartphones in Japan. Furthermore, the students reported that they rarely used computer labs for printing as the labs at Osaka University are not always equipped with printers.

Similar to the results of Winke and Goertler (2008a, b), Goertler (2009), and Goertler et al. (2012), the students' ownership of and access to devices specific to CALL (e.g., headphones, webcams, microphones, and speakers) were limited. However, this does not pose any problems for online language learning and teaching, since smartphones and laptops are equipped with advanced features such as audio/video recording. Moreover, Osaka University provides necessary hardware and software support for online education at CALL classrooms, computer labs, and learning commons on campus. As emphasized by Winke and Goertler (2008b), the students should be aware of the availability of these facilities which is addressed by holding orientation sessions known as "PC Guidance" at Osaka University. 
Contrary to what one might expect, the participants' computer use was restricted to less than two hours a day. This can be accounted for by reference to the prevalent use of handheld devices to access the Internet. Therefore, there is a possibility that the students would tend to use smartphones for daily life activities and entertainment more often than computers, thus the limited hours of computer use.

\section{Digital literacy and competence}

The participants were in general found to be able to perform basic computer-based tasks (e.g., keyboarding and formatting documents, surfing the Internet, playing audio/ video files), yet unable to do more advanced tasks (e.g., creating multimedia documents using word processing software and recording and editing audio/video files, which was far from expected).

The participants also believed their English typing skills to be poor. Typing in English, though simple at first glance, is a challenging task for Japanese learners as observed by McDonald and Foss (2007, 2009), Kobayashi and Little (2011), and Gondree (2013). This inability could be attributed to the different Japanese input methods as well as the excessive use of virtual keyboards on mobile devices. Consequently, despite being familiar with the layout of QWERTY keyboards, Japanese university students find it difficult to type in English. This could also be in view of the fact that many Japanese university students do not use word processing software as found by Murray and Blyth (2011).

With regard to familiarity with and use of multimedia tools, the students were in general acquainted with a number of tools and tasks used in daily life such as social networking systems, sending and receiving emails, and navigating websites. Nonetheless, not all of them were familiar with Second Life, podcasts/videocasts, and surprisingly iPads and iPods. These findings are in accord with previous studies (e.g., Goertler 2009; Goertler et al. 2012; Winke and Goertler 2008b) indicating that the participants are avid users of ICT for personal but not for educational purposes.

According to the Organization for Economic Co-operation and Development (OECD 2015), computer access and use are comparatively low in Japanese schools which could explain the discrepancy between the students' expected and observed levels of ICT proficiency. In line with this observation, the participants of the current study were also found to be mostly unaware of the usefulness of CALL tools in English language education. In fact, the availability of technology in high-resource contexts does not guarantee its effective use as highlighted by Egbert and Yang (2004) and Warschauer (2002, 2011).

\section{Willingness to experience online learning}

The participants' responses in this study were characterized by a general lack of interest in taking fully online or blended courses of English. Winke and Goertler (2008b) accounted for the "fear" of online language learning as a form of apprehension toward the dynamics of online socialization. They also made reference to student preferences and learning styles as two other causes of lack of interest in hybrid/online courses. Goertler (2009) also found her participants to be opposing online language learning on the grounds that they had low access to tech tools, were not confident of their computer skills, had little if any CALL experience, and favored face-to-face instruction over learning from a computer. Following that, Goertler et al. (2012) also indicated students' 
preference for instructor presence as the major factor behind dismissing hybrid language education as being inferior to the face-to-face mode of teaching. Similarly, Winke et al. (2010) faced the challenge of student unwillingness to adopt hybrid language learning. As all four studies have argued, learner training is of crucial importance in dispelling the myths surrounding hybrid language instruction. Training students to accomplish advanced CALL tasks can help promote a positive attitude toward online language learning and thus lead to improved learning outcomes (Hubbard 2005). In addition, maintaining a positive attitude could enable learners to confront the challenges of e-learning and could raise their awareness of the benefits of CALL (Lockley and Promnitz-Hayashi 2012).

\section{Are Japanese digital natives ready for learning english online?}

Based on the results of this study, the answer to this question is clearly "no". Goertler (2009) explains that one cannot assume that a digital native is necessarily ready to learn in an online environment. Digital natives may be capable of utilizing ICT in everyday life, but those skills are not always transferable to pedagogical environments (Ushida 2005). As a result, it is prudent to avoid interpreting the term digital native too broadly as covering the entire population of university-age learners (Gobel and Kano 2014; MacLean and Elwood 2009). A similar observation has been made by Bennett et al. (2008) and Bennett and Maton (2010) who reported a general unwillingness among their digital natives to make use of technology for educational purposes. By and large, Japanese keitai (携帯: mobile phone) natives also tend to use their phones for gaming, entertainment, and personal communication far more than for educational activities (Lockley and Promnitz-Hayashi 2012), which could be a contributing factor to the relatively low self-ratings on items asking the participants about their ability to make effective use of technology for CALL tasks.

\section{Conclusion}

Overall, the results of this study indicate that students have personal ownership and sufficient access to digital devices as well as the Internet either at home or on campus. Despite having low keyboarding skills in English, they also have a fair command of knowledge and practice of general Web 2.0 tools for daily life, but not for educational purposes. The majority of the students are also reluctant to take online courses which makes CALL-focused digital literacy training an essential element in implementing the prospective EGAP online course. A handful of studies have also demonstrated that specific training on CALL tools and applications is a prerequisite prior to performing online tasks, and ongoing technical support is a necessity as well (e.g., Barrette 2001; Kabata et al. 2005; Romeo and Hubbard 2011).

The current study has implications for designing and implementing the prospective EGAP online course. First, with regard to student preference for smartphones, the course content should be made available on both desktop computers and mobile devices (Blackboard Mobile Learn ${ }^{\mathrm{Tm}}$ application in the case of Osaka University). Furthermore, edutainment and gamification should be the integral components of the course due to their motivating nature for Japanese learners. It is worth noting that the same questionnaire with minor modifications will be administered to the students who 
will be enrolled in the future SPOC with the aim of measuring their level of ereadiness. Considering Japanese learners' difficulties with comprehending English as evidenced in the authors' language needs analysis at Osaka University submitted for publication, some L1 translations will be provided in the orientation sessions and online tutorials of the future course, since "comprehension is the main goal, rather than language learning or practice" in effective CALL learner training (Hubbard 2004, p. 57).

Since a self-assessment questionnaire has been used in this study, the responses are likely to be culturally biased under the influence of self-effacement and low selfconfidence (Iwamoto 2007). Another limitation of this study is the sample size which makes the findings less generalizable to the overall population of Japanese university students.

To the best of the researchers' knowledge, no earlier survey has been conducted at Osaka University to investigate the readiness of Japanese students for online language education. Future replication studies could thus examine the impact of gender, field of study, age, and socio-economic status on learner e-readiness with a larger sample size as additional factors influencing learners' interest in hybrid language education. Potential research questions are as follows: Do males and females differ in their computer access and literacy levels? Are there any differences between students majoring in humanities versus science and engineering with reference to their e-readiness? Does the number of years spent at the university make any difference in student e-readiness levels? Does the socio-economic status of the students make any difference in their willingness to take online/blended courses?

\section{Additional file}

Additional file 1: The Japanese Translation of Technology Survey. (DOCX 35 kb)

\section{Acknowledgements}

We would like to thank the instructors at Osaka University who helped us with data collection and all the students who participated in our survey.

\section{Authors' contributions}

All authors read and approved the final manuscript.

Competing interests

The authors declare that they have no competing interests.

\section{Author details}

${ }^{1}$ Cybermedia Center, Toyonaka Educational Research Center, Osaka University, 1-32 Machikaneyama, Toyonaka, Osaka 560-0043, Japan. ²Department of Language and Culture, Graduate School of Language and Culture, Osaka University, 1-8 Machikaneyama-cho, Toyonaka, Osaka 560-0043, Japan.

Received: 25 August 2016 Accepted: 14 November 2016

Published online: 13 March 2017

\section{References}

Aisami, R. S. (2009). Planning and teaching online courses. In P. L. Rogers, G. A. Berg, J. V. Boettcher, C. Howard, L. Justice, \& K. D. Schenk (Eds.), Encyclopedia of distance learning (2nd ed., pp. 1628-1638). Hershey: IGI Global. doi:10.4018/978-1-60566-198-8.

Akaslan, D., \& Law, E. L. C. (2011). Measuring student e-learning readiness: A case about the subject of electricity in higher education institutions in Turkey. In H. Leung, E. Popescu, Y. Cao, R. W. H. Lau, \& W. Nejdl (Eds.), Advances in Web-based learning - ICWL 2011 (pp. 209-218). Heidelberg: Springer. doi:10.1007/978-3-642-25813-8.

Aoki, K. (2015). MOOCs and open education in Japan: The case of the Open University of Japan. In C. J. Bonk, M. M. Lee, T. C. Reeves, \& T. H. Reynolds (Eds.), MOOCs and open education around the world (pp. 21-29). New York, NY: Routledge.

Barrette, C. M. (2001). Students' preparedness and training for CALL. CALICO Journal, 19(1), 5-36. doi:10.1558/cj.v19i1.5-36. 
Bates, A. W., \& Sangrà, A. (2011). Managing technology in higher education: Strategies for transforming teaching and learning. San Francisco: Jossey-Bass.

Bax, S. (2011). Normalisation revisited: The effective use of technology in language education. International Journal of Computer-Assisted Language Learning and Teaching, 1(2), 1-15. doi:10.4018/ijcallt.2011040101.

Bennett, S. J., \& Maton, K. A. (2010). Beyond the 'digital natives' debate: Towards a more nuanced understanding of students' technology experiences. Journal of Computer Assisted Learning, 26(5), 321-331. doi:10.1111/j.1365-2729.2010.00360.x.

Bennett, S. J., Maton, K. A., \& Kervin, L. K. (2008). The 'digital natives' debate: A critical review of the evidence. British Journal of Educational Technology, 39(5), 775-786. doi:10.1111/j.1467-8535.2007.00793.x.

Blake, R. J. (2011). Current trends in online language learning. Annual Review of Applied Linguistics, 31, 19-35. doi:10.1017/S026719051100002X.

Blyth, A. (2015). Social media ethics in English language teaching. JALT CALL Journal, 11(2), 165-176. http://journal. jaltcall.org/articles/11_2_Blyth.pdf. Accessed 27 June 2016.

Bracher, J. (2013). A survey of online teaching by native-speaker English instructors at Japanese universities. JALT CALL Journal, 9(3), 221-239. http://journal.jaltcall.org/articles/9_3_Bracher.pdf. Accessed 31 July 2016.

Burrows, T., \& Stepanczuk, D. (2013). Gauge of readiness for Internet-based language learning: An 800 Ib GORILLa. JALT CALL Journal, 9(2), 197-217. http://journal.jaltcall.org/articles/9_2_Burrows.pdf. Accessed 18 June 2016.

Butler-Pascoe, M. E., \& Wiburg, K. W. (2003). Technology and teaching English language learners. Boston: Allyn and Bacon.

Chiou, C. Y., Mohd Ayub, A. F., \& Luan, W. S. (2010). Students' readiness in using mathematics online portal: A preliminary study among undergraduates. Procedia - Social and Behavioral Sciences, 2(3), 677-681. doi:10.1016/j.sbspro.2010.03.083.

Chong, M. C., Sellick, K., Francis, K., \& Abdullah, K. L. (2011). What influences Malaysian nurses to participate in continuing professional education activities? Asian Nursing Research, 5(1), 38-47. doi:10.1016/S1976-1317(11)60012-1.

Cybermedia Center. (2013). Cybermedia center outline. http://www.cmc.osaka-u.ac.jp/wp-content/uploads/2014/11/ e31c91a04f225ad482766599d4b59927.pdf. Accessed 9 July 2016.

Egbert, J., \& Yang, Y. (2004). Mediating the digital divide in CALL classrooms: Promoting effective language tasks in limited technology contexts. ReCALL Journal, 16(2), 280-291. doi:10.1017/S0958344004000321.

Fageeh, A. I. (2011). EFL students' readiness for e-learning: Factors influencing e-learners' acceptance of the Blackboard in a Saudi university. JALT CALL Journal, 7(1), 19-42. http://journal.jaltcall.org/articles/11_1_Fageeh.pdf. Accessed 5 July 2016.

Fujita, K., Morimoto, T., Ike, M., Okunishi, Y. \& Harashima, S. (2009). 大阪大学工学部 工学研究科の海外夏期英語研 修への挑戦 [A new way forward: Intensive English courses for science and engineering students]. 生産と技術, 61 (4), 101-104. http://seisan.server-shared.com/614/614-101.pdf. Accessed 9 July 2016.

Gobel, P., \& Kano, M. (2014). Mobile natives: Japanese university students' use of digital technology. In J. B. Son (Ed.), Computer-assisted language learning: Learners, teachers and tools (pp. 21-46). Newcastle: Cambridge Scholars.

Goertler, S. (2009). Hybridizing the curriculum: Needs, benefits, challenges, and attitudes. In R. Oxford \& J. Oxford (Eds.), Second language teaching and learning in the Net generation (pp. 53-64). Manoa: National Foreign Language Resource Center.

Goertler, S., Bollen, M., \& Gaff, J. (2012). Students' readiness for and attitudes toward hybrid FL instruction. CALICO Journal, 29(2), 297-320. https://journals.equinoxpub.com/index.php/CALICO/article/download/23730/22585. Accessed 5 July 2016.

Gondree, E. (2013). Problems of computer keyboarding in an EFL context. OnCUE Journal, 7(3), 180-187. http://www. jaltcue.org/files/OnCUE/OCJ7.3/OCJ7.3_pp180-187_Gondree.pdf. Accessed 16 July 2016.

Guglielmino, L. M., \& Guglielmino, P. J. (2003). Identifying learners who are ready for e-learning and supporting their success. In G. M. Piskurich (Ed.), Preparing learners for e-learning (pp. 19-33). San Francisco: Pfeiffer.

Hino, N., \& Oda, S. (2015). Integrated Practice in Teaching English as an International Language (IPTEIL): A classroom ELF pedagogy in Japan. In Y. Bayyurt \& S. Akcan (Eds.), Current perspectives on pedagogy for English as a lingua franca (pp. 35-50). Berlin: De Gruyter Mouton.

Hockly, N. (2015). Developments in online language learning. ELT Journal, 69(3), 308-313. doi:10.1093/elt/ccv020.

Hubbard, P. (2004). Learner training for effective use of CALL. In S. Fotos \& C. Browne (Eds.), New perspectives on CALL for second language classrooms (pp. 45-67). Mahwah: Lawrence Erlbaum.

Hubbard, P. (2005). A review of subject characteristics in CALL research. Computer Assisted Language Learning, 18(5), 351-368. doi:10.1080/09588220500442632.

Hubbard, P. (2013). Making a case for learner training in technology enhanced language learning environments. CALICO Journal, 30(2), 163-178. doi:10.11139/cj.30.2.163-178.

Hubbard, P., \& Bradin Siskin, C. (2004). Another look at tutorial CALL. ReCALL, 16(2), 448-461. doi:10.1017/S0958344004001326.

Hung, M. L., Chou, C., Chen, C. H., \& Own, Z. Y. (2010). Learner readiness for online learning: Scale development and student perceptions. Computers \& Education, 55(3), 1080-1090. doi:10.1016/j.compedu.2010.05.004.

Iwamoto, N. (2007). Is self-assessment possible? Japanese students' self-assessment in their course work. Studies in English Linguistics and Literature, 17, 65-79. http://www.jaell.org/gakkaishi17th/Noriko\%20IWAMOTO.pdf. Accessed 17 July 2016.

Kabata, K., Wiebe, G., \& Chao, T. (2005). Challenge of developing and implementing multimedia courseware for a Japanese language program. CALICO Journal, 22(2), 237-250. doi:10.1558/cj.v22i2.237-250.

Kassen, M., \& Lavine, R. (2007). Developing advanced level foreign language learners with technology. In M. Kassen, R. Lavine, K. Murphy-Judy, \& M. Peters (Eds.), Preparing and developing technology-proficient L2 teachers (pp. 233-262). San Marcos: CALICO.

Kobayashi, K., \& Little, A. (2011). Learner perceptions on the usefulness of a blended learning EFL program. JALT CALL Journal, 7(1), 103-117. http://journal.jaltcall.org/articles/7_1_Kobayashi.pdf. Accessed 16 July 2016.

Koguchi, I. (2003). CALL と英語教育一言語文化部英語教室の取り組み [CALL and English education: Efforts of the Department of Language and Culture at establishing CALL classrooms]. Cybermedia Forum, 4, 36-39. http://www. cmc.osaka-u.ac.jp/publication/for-2003/36-39.html. Accessed 9 July 2016.

Levy, M. (2006). Effective use of CALL technologies: Finding the right balance. In R. P. Donaldson \& M. A. Haggstrom (Eds.), Changing language education through CALL (pp. 1-18). New York: Routledge. 
Lockley, T., \& Promnitz-Hayashi, L. (2012). Japanese university students' CALL attitudes, aspirations and motivations. CALL-EJ, 13(1), 1-16. http://callej.org/journal/13-1/Lockley_Promnitz-Hayashi_2012.pdf. Accessed 16 July 2016.

MacLean, G. R., \& Elwood, J. A. (2009). Digital natives, learner perceptions and the use of ICT. In M. Thomas (Ed.), Handbook of research on Web 2.0 and second language learning (pp. 156-179). Hershey: IGl Global. doi:10.4018/978-1-60566-190-2.

McCarty, S. (2007). Theorizing and realizing the globalized classroom. In A. Edmundson (Ed.), Globalized e-learning cultural challenges (pp. 90-115). Hershey: Information Science.

McCarty, S. (2009). Social networking behind student lines in Japan. In M. Thomas (Ed.), Handbook of research on Web 2. 0 and second language learning (pp. 181-201). Hershey: IGI Global. doi:10.4018/978-1-60566-190-2.

McDonald, K., \& Foss, P. (2007). A look at first-year students' English typing abilities. OnCUE Journal, 1(1), 55-63. http:// jaltcue.org/files/OnCUE/OCJ1-1articles/2007OCJ1-1-McDonaldFoss-p55-p63.pdf. Accessed 16 July 2016.

McDonald, K., \& Foss, P. (2009). Another look at first-year students' English typing abilities. OnCUE Journal, 3((1), 48-66. http://jaltcue.org/files/OnCUE/OCJ3-1articles/OCJ3-1-McDonald-Foss-pp48-66.pdf. Accessed 16 July 2016.

MEXT. (2011). The vision for ICT in education: Toward the creation of a learning system and schools suitable for the $21^{\text {st }}$ century. http://www.mext.go.jp/b_menu/houdou/23/04/_icsFiles/afieldfile/2012/08/03/1305484_14_1.pdf. Accessed 1 October 2016.

Ministry of Internal Affairs and Communications. (2012). Information and communication in Japan [White paper]. http:// www.soumu.go.jp/johotsusintokei/whitepaper/eng/WP2012/2012-outline.pdf. Accessed 30 June 2016.

Moore, M. G. (Ed.). (2013). Handbook of distance education (3rd ed.). New York: Routledge.

Murray, A., \& Blyth, A. (2011). A survey of Japanese university students' computer literacy levels. JALT CALL Journal, 7(3), 307-318. http://journal.jaltcall.org/articles/7_3_Murray.pdf. Accessed 17 July 2016.

$\mathrm{Ng}, \mathrm{W}$. (2015). New digital technology in education: Conceptualizing professional learning for educators. London: Springer. doi:10.1007/978-3-319-05822-1.

Nishikawa, M., Nakajima, M. Iwai, Katakura, Y., Fujiyama, K. Gambe, A. E., ..., Fukui, K. (2006). Development of e-learning contents for English for Specific Purposes (ESP) in science and technology. Proceedings of the APRU DLI, 31-38. http://citeseerx.ist.psu.edu/viewdoc/download?doi=10.1.1.131.8437\&rep=rep1\&type=pdf Accessed 9 July 2016.

Noguchi, J. (2003). Teaching ESP writing: OCHA in a CALL class. Cybermedia Forum, 4, 40-45. http://www.cmc.osaka-u. ac.jp/publication/for-2003/40-45.html. Accessed 22 July 2016.

OECD. (2015). Students, computers and learning: Making the connection. Paris: OECD. doi:10.1787/9789264239555-en.

Palmer, S. R., \& Holt, D. M. (2009). Examining student satisfaction with wholly online learning. Journal of Computer Assisted Learning, 25(2), 101-113. doi:10.1111/j.1365-2729.2008.00294.x.

Prensky, M. (2001). Digital natives, digital immigrants. On the Horizon, 9(5), 1-6. doi:10.1108/10748120110424816.

Romeo, K., \& Hubbard, P. (2011). Pervasive CALL learner training for improving listening proficiency. In M. Levy, F. Blin, C. Bradin Siskin, \& O. Takeuchi (Eds.), WorldCALL: International perspectives on computer-assisted language learning (pp. 215-229). New York: Routledge.

Shudong, W., Higgins, M., \& Shima, Y. (2005). Training English pronunciation for Japanese learners of English online. JALT CALL Journal, 1(1), 39-47. http://journal.jaltcall.org/articles/1_1_Wang.pdf. Accessed 17 July 2016.

Smith, P. J. (2005). Learning preferences and readiness for online learning. Educational Psychology, 25(1), 3-12. doi:10. 1080/0144341042000294868.

Son, J., Robb, T., \& Charismiadji, I. (2011). Computer literacy and competency: A survey of Indonesian teachers of English as a foreign language. CALL Electronic Journal, 12(1), 26-42. http://callej.org/journal/12-1/Son_2011.pdf. Accessed 17 July 2016

Takefuta, J. (2015a). Implementation report for online public course "English for Science". In N. Hino, J. Takefuta, S. Oda, \& S. Yu (Eds.)，これ からの英語教育 [Future of English education] (pp. 13-22). Osaka: Graduate School of Language and Culture, Osaka University. http://ir.library.osaka-u.ac.jp/dspace/bitstream/11094/53780/4/gbkp_2014_k_013.pdf _013.pdf. Accessed 9 July 2016.

Takefuta, J. (2015b). Listen to me!シリーズ: Introduction to college life 用. Tokyo: BookWay.

Takemura, H. (2012). Supporting university projects using LMS (Technical Report No. 7). Retrieved from Information Processing Society of Japan website: https://ipsj.ixsq.nii.ac.jp/ej/index.php?active_action=repository_view_main_ item_detail\&page_id=13\&block_id=8\&item_id=86284\&item_no=1=coz0thy3Xmm3IW.

Thornton, P., \& Houser, C. (2002). M-learning in transit. In P. Lewis (Ed.), The changing face of CALL (pp. 229-243). Lisse: Swets and Zeitlinger.

Thornton, P., \& Houser, C. (2003). Using mobile web and video phones in English language teaching: Projects with Japanese college students. In B. Morrison, C. Green, \& G. Motteram (Eds.), Directions in CALL: Experience, experiments and evaluation (pp. 207-224). Hong Kong: Hong Kong Polytechnic University.

Thornton, P., \& Houser, C. (2005). Using mobile phones in English education in Japan. Journal of Computer Assisted Learning, 21(3), 217-228. doi:10.1111/j.1365-2729.2005.00129.x.

Ushida, E. (2005). The role of students' attitudes and motivation in second language learning in online language courses. CALICO Journal, 23(1), 49-78. https://calico.org/html/article_131.pdf. Accessed 17 July 2016.

Ward, M. (2015). Factors in sustainable CALL. In A. Gimeno-Sanz, M. Levy, F. Blin, \& D. Barr (Eds.), WorldCALL: Sustainability and computer-assisted language learning (pp. 132-151). New York: Bloomsbury.

Warner, D., Christie, G., \& Choy, S. (1998). Readiness of VET clients for flexible delivery including on-line learning. Brisbane: Australian National Training Authority.

Warschauer, M. (2002). Reconceptualizing the digital divide. First Monday, 7(7). http://firstmonday.org/article/view/967/ 888/. Accessed 16 July 2016

Warschauer, M. (2011). Learning in the cloud: How (and why) to transform schools with digital media. New York: Teachers College Press.

Watkins, R., Leigh, D., \& Triner, D. (2004). Assessing readiness for e-learning. Performance Improvement Quarterly, 17(4), 66-79. doi:10.1111/j.1937-8327.2004.tb00321.x

Winke, P. M., \& Goertler, S. (2008a). An introduction to distance language learning. In S. Goertler \& P. Winke (Eds.), Opening doors through distance language education: Principles, perspectives, and practices (pp. 1-10). San Marcos: CALICO. 
Winke, P. M., \& Goertler, S. (2008b). Did we forget someone? Students' computer access and literacy for CALL. CALICO Journal, 25(3), 482-509. https://calico.org/html/article_713.pdf. Accessed 19 June 2016.

Winke, P., Goertler, S., \& Amuzie, G. L. (2010). Commonly taught and less commonly taught language learners: Are they equally prepared for CALL and online language learning? Computer Assisted Language Learning, 23(3), 53-70. doi:10.1080/09588221.2010.486576

Xiong, Y., So, H. J., \& Toh, Y. (2015). Assessing learners' perceived readiness for computer supported collaborative learning (CSCL): A study on initial development and validation. Journal of Computing in Higher Education, 27(3), 215-239. doi:10.1007/s12528-015-9102-9.

Submit your manuscript to a SpringerOpen ${ }^{\circ}$ journal and benefit from:

- Convenient online submission

- Rigorous peer review

- Immediate publication on acceptance

- Open access: articles freely available online

- High visibility within the field

- Retaining the copyright to your article

Submit your next manuscript at $>$ springeropen.com 